\title{
MENINGKATKAN HASIL BELAJAR PESERTA DIDIK KELAS IV SEKOLAH DASAR NEGERI LIMO 3 DEPOK PADA MATA PELAJARAN IPS MATERI KEGIATAN EKONOMI MELALUI MEDIA GAMBAR DAN METODE DEMONSTRASI
}

\author{
NURILAH ${ }^{1}$ \\ Guru SDN Limo 2 Depok \\ Wahyu Bagja Sulfemi ${ }^{2}$ \\ STKIP Muhammadiyah Bogor \\ surel:wahyubagja@gmail.com
}

\begin{abstract}
ABSTRAK
Penelitian ini dilakukan untuk meningkatkan belajar peserta didik dalam materi kegiatan ekonomi. Apakah penggunaan media gambar dan metode demonstrasi dapat meningkatkan hasil belajar IPS siswa kelas IV SD Negeri Limo 3 ?. subjek penelitian ini dilakukan melihat pencapaian $\mathrm{kkm}$ yang dicapai, dimulai dari pra Siklus. Dari data yang diperoleh 36 peserta didik, memperoleh hasil: 16 peserta didik yang mendapat niali kurang, 18 peserta didik yang mendapat nilai sedang dan hanya 2 peserta didik yang mendapat nilai baik. Berlanjut pada siklus I, terjadi peningkatan terhadap nilai yang dipeoleh oleh peserta didik , diantaranya: hanya 8 peserta didik yang mendapat nilai kurang, 22 peserta didik yang mendapat nilai sedang, dan 6 peserta didik yang mendapat nilai baik. Dirasa masih jauh dari harapan nilai nilai yang diperoleh oleh para peserta didik, maka peneliti melanjutkan perbaikan pembelajaran pada siklus II, pada siklus II terjadi peningkatan yang segnifikan, tidak ada peserta didik yang mendapat nilai kurang, 15 peserta didik yang mendapat nilai sedang, dan 21 peserta didi yang mendapat nilai sangat baik. Dari data tersebut, terjadi peningkatan yang sangat segnifikan di dalam "Metode Demonstrasi dan Media Gambar pada Materi Kegiatan Ekonomi di SD Negeri Limo 3”.
\end{abstract}

Kata Kunci : :Metode Demonstrasi, Media Gambar,dan Hasil belajar .

\section{PENDAHULUAN}

\section{A. Latar Belakang Masalah}

Ilmu Pengetahuan Sosial (IPS) merupakan mata pelajaran yang mengkaji beragam aktifitas kehidupan manusia dalam berbagai dimensi kehidupan sosial sesuai dengan karakteristik manusia sebagai makhluk sosial. 
Menyadari betapa pentingnya mata pelajaran IPS pada jenjang sekolah dasar, maka pembelajaran IPS harus ditingkatkan sehingga hasil belajar siswa dapat tercapai sesuai dengan kriteriteria ketuntasan minimal (KKM) yang diterapkan.

Betapa kondisi pembelajaran Ilmu Pengetahuan Sosial selama ini kurang mendukung terhadap tujuan pendidikan Ilmu Pengetahuan Sosial itu sendiri. Ini ditandai dengan proses pembelajaran yang masih bersifat tradisional tersebut yang dimana disebabkan oleh pradigma lama bahwa Ilmu Pengetahuan Sosial merupakan struktur ilmu pengetahuan yang tidak jelas.

Peran guru sebagai infrastruktur perlu mengalami pergeseran menjadi fasilitator atau pemandu dalam belajar karena hal ini akan berpengaruh kepada hasil belajar yang akan diraih oleh para pes. SD Negeri Limo 3 nilai rata-rata siswa pada saat penelitian prasiklus pembelajaran IPS materi kegiatan ekonomi dilingkungan sekitar, dari 36 peserta didik, 12 peserta didik sudah memahami atau sebanyak 33,33\% sudah mencapai tingkat penguasaan, sedangkan yang belum berhasil sebanyak 24 orang peserta didik belum berhasil atau 66,67\%, nilai ratarata yang diperoleh pada pembelajaran prasiklus 61,8 dibawah $\mathrm{KKM}$ yang telah ditentukan $(70,00)$.

Salah satu cara untuk meningkatkan hasil belajar peserta didik SD Negeri Limo 3 dalam proses pembelajaran adalah dengan mengganti media dan model pembelajaran untuk meningkatkan hasil belajar, tidak seperti metode pembelajaran yang dilakukan dengan ceramah dan tanyajawab, model pembelajaran ini membuat siswa jenuh dan tidak kreatif. Suasana belajar mengajar yang diharapkan adalah menjadikan siswa sebagai subjek yang berupaya menggali sendiri, memecahkan sendiri masalah-masalah dari suatu konsep yang dipelajari, sedangkan guru lebih banyak bertindak sebagai motivator dan fasilitator. Situasi belajar yang diharapkan di sini adalah siswa yang lebih banyak berperan (kreatif). 
Berdasarkan uraian diatas penulis merasa tertarik untuk melakukan PTK (penelitian tindakan kelas) dengan judul " Meningkatkan Hasil Belajar Peserta Didik Kelas IV SD Negeri Limo 3 Depok Pada Mata Pelajaran IPS Materi Kegiatan Ekonomi Melalui Media Gambar Dan Metode Demonstrasi

\section{Identifikasi Masalah}

Berdasarkan uraian di atas, kegiatan refleksi guru, dan diskusi dengan teman sejawat terhadap proses pembelajaran IPS, serta dilengkapi dengan data-data dan hasil observasi yang menunjang, maka ditemukan satu kondisi pembelajaran yang kurang kondusif diantaranya :

A. Peserta didik belum memahami materi pelajaran

B. Pembelajaran membosankan bagi peserta didik

C. Peserta didik kurang bersemangat ketika proses belajar berlangsung

D. Peserta didik kurang aktif mengikuti pelajaran

E. Hasil belajar masih banyak dibawah KKM yang telah ditetapkan.

\section{Analisis Masalah}

Setelah penulis mengidentifiksikan masalah yang terjadi, maka ditemukan penyebab peserta didik kurang memahami materi belajar yaitu :
A. Guru kurang mempersiapkan materi yang akan diajarkan.
B. Guru tidak menggunakan metode pembelajaran.
C. Guru kurang memberikan motivasi kepada peserta didik.
D. Interaksi antara guru dengan murid tidak berjalan dengan baik.
E. Media pembelajaran yang digunakan kurang bervariasi.

\section{Jawaban Pemecahan Masalah}

Dari hasil uraian diatas, yang menjadi sebagai fokus perbaikan pembelajaran adalah sebagai berikut : 
A. Guru harus memperluas materi yang akan diajarkan.

B. Guru harus menggunakan metode pembelajaran yang sesuai dengan materi pembelajaran.

C. Guru harus memberikan motivasi belajar kepada peserta didik.

D. Guru harus berinteraksi dengan peserta didik.

E. Guru harus menggunakan media pembelajaran yang bervariasi sesuai dengan materi yang disampaikan.

\section{B. Rumusan Masalah}

Berdasarkan pembatasan masalah diatas, permasalahan dalam penelitaian ini dirumuskan sebagai berikut : Bagaimana meningkatkan hasil belajar peserta didik kelas IV SD Negeri Limo 3 Depok Pada Mata Pelajaran IPS Materi Kegiatan Ekonomi Melalui Media Gambar Dan Metode Demonstrasi

\section{Tujuan Penelitian}

Tujuan diadakannya penelitian ini adalah untuk meningkatkan hasil belajar peserta didik pada pelajaran IPS materi kegiatan ekonomi melalui media gambar dan metode demonstrasi.

\section{Manfaat Penelitian}

Penelitian ini diharapkan dapat memberikan manfaat untuk semua pihak yang bersangkutan dalam penelitian ini. Manfaat yang diperoleh, yaitu sebagi berikut :

a. Bagi peneliti

1) Mengembangkan wawasan dan menambah informasi mengenai pengetahuan penggunaan metode demonstrasi dan media gambar pembelajaran di dalam hasil belajar peserta didik.

2) Untuk mengukur seberapa besar nilai yang dicapai peserta didik dalam pembelajaran IPS dengan metode demonstrasi dan media gambat 
b. Bagi Guru

1) Untuk membangkitkan kreativitas guru dalam menentukan metode demonstrasi dan media gambar yang tepat dalam proses pembelajaran.

2) Meningkatkan hasil belajar peserta didik.

c. Bagi Siswa

1) Meningkatkan minat dan aktivitas peserta didik dalam kegiatan pembelajaran.

2) Agar lebih mandiri serta dapat berinteraksi antara sesama siswa maupun guru dalam pembelajaran.

d. Bagi sekolah

Meningkatkan hasil belajar pada mata pelajaran IPS serta meningkatkan citra sekolah.

\section{KAJIAN PUSTAKA}

\section{A. Hasil Belajar IPS}

Hasil belajar merupakan kemampuan-kemampuan yang dimiliki siswa setelah ia menerima pengalaman belajarnya. Hasil belajar digunakan oleh guru untuk dijadikan ukuran atau kriteria dalam mencapai suatu tujuan pendidikan.

Menurut Purwanto (2011:45) hasil belajar adalah perubahan prilaku manusia akibat belajar. Perubahan prilaku disebabkan karena dia mencapai penguasaan atas sejumlah bahan yang diberikan dalam proses belajar mengajar. Pencapaian itu didasarkan atas tujuan pengajaran yang telah ditetapkan. Hasil itu dapat berupa perubahan dalam aspek kognitif, afektif maupun psikomotorik.

Melalui prilaku yang terdapat pada peserta didik seorang guru dapat mengetahui apakah setelah dilakukah proses pembelajaran peserta didik mendapat hasil belajar yang baik ataukah sebaliknnya. Istilah IPS disekolah dasar merupakan nama mata pelajaran yang berdiri sendiri 
sebagai integrasi dari sejumlah konsep ilmu sosial, humaniora sains bahkan berbagai isu dan masalah sosial kehidupan (Sapriya (2014:20))

Sesuai dengan tujuan Ilmu Pengetahuan Sosial yaitu agar para peserta didik dapat memahami eksistensi dirinya sebagai mahluk hidup, yang harus berkembang, berinteraksi, berusaha memenuhi kebutuhan hidupnya, serta mampu berinteraksi dengan sesama manusia dalam rangka mengembangkan budaya kehidupan. Peranan ilmu pengetahuan sosial diharapkan dapat mendewasakan diri dan kepribadian peserta didik, sehingga mampu membina sampai menjadi manusia yang mandiri, sadar akan hak dan kewajibannya, dan dapat memecahkan berbagai masalah kehidupan yang dihadapinya ( Umar H (2012:205)).

Dari pendapat diatas, maka disimpulkan bahwa hasil belajar siswa dipengaruhi oleh dua factor yaitu dari dalam individu siswa yaitu berupa kemampuan professional dan faktor dari luar diri siswa yakni lingkungan dan masyarakat.

\section{B. Metode Demonstrasi}

Metode pembelajaran adalah cara-cara menyajikan materipelajaran yang dilakukan oleh pendidik agar terjadi proses belajar pada diri siswa dalam upaya untuk mencapai tujuan. Menurut Sudirman (1991:132) Metode demonstrasi adalah cara penyajian pelajaran dengan meragakan atau mempertunjukan kepada siswa atau proses, situasi atau benda tertentu yang sedang dipelajari, baik sebenarnya atupun tiruan, yang sering disertai dengan penjelasan lisan.

Metode demonstrasi memiliki beberapa kelebihan, diantaranya :

1. Metode ini dapat berupa pengajaran menjadi lebih jelas dan lebih kongkrit

2. Siswa diharapka lebih mudah dalam memahami apa yang sedang di pelajari

3. Proses pengajaran akan lebih menarik 
4. Siswa dirangsang untuk aktif mengamati, menyesuaikan antara teori dengan kenyataan, dan mencoba melakukan sendiri.

5. Metode ini dapat disajikan materi pelajaran yang tidak mungkin atau kurang sesuai dengan menggunakan metode lain.

Kekurangan metode demonstarsi antara lain :

1. Metode ini memerlukan keterampilan guru secara khusus, karena tanpa ditunjang dengan hal itu pelaksanaan demonstrai akan tidak efektif.

2. Fasilitas seperti peralatan, tempat dan biaya yang memadai tidak selalu tersedia dengan baik.

3. Demonstrasi memerlukan kesiapan dan perencanaan yang matang disamping sering memerlukan waktu yang cukup panjang.

Dengan demikian, salah satu keterampilan guru yang memegang peranan penting dalam proses pembelajaran adalah keterampilan memilih metode. Pemilihan metode berkaitan langsung dengan usaha-usaha guru dalam menampilkan pembelajaran yang sesuai dengan situasi dan kondisi sehingga pencapaian tujuan pembelajaran diperoleh secara optimal.

Penggunaan metode yang monoton dalam membelajarkan akan menyebabkan siswa cepat jenuh. Dalam membelajarkan, guru sebaiknya terlebih dahulu mengetahui tipe masing-masing siswa metode pembelajaran yang tepat dan efektif.

Sebagaimana dari pengertian diatas penulis dapat merumuskan bahwa metode demonstrasi merupakan cara penyampaian pembelajaran seorang guru kepada peserta didik yang identik dengan metode mengajar modeling, dimana seorang guru harus benar-benar menguasai materi yang akan didemonstrasikan dengan menggunakan bantuan alat peraga, benda tiruan dan juga penjelasan secara lisan.

\section{Media Gambar}

Kehadiran media mempunyai arti yang cukup penting dalam kegiatan belajar mengajar. Ketidak jelasan suatu materi pembelajaran 
dapat dibantu dengan adanya media sebagai perantara atau pemberi informasi. Penyampaian bahan dan materi yang sulit bagi siswa dapat disederhanakan dan diperjelas dengan bantuan media. Dengan adanya media siswa lebih mudah menerima dan memahami materi pembelajaran dibandingkan dengan ketidak adaan media pembelajaran.

Menurut Trianto (2009:234) Media adalah suatu ekstensi manusia yang memungkinkannya mempengaruh orang lain yang tidak mengadakan kontak langsung dengannya. Media gambar adalah media yang dihasilkan dengan cara dicetak melalui teknik manual atau dengan dibuat dengan cara menggambarkan atau melukis, printingdan sablon. Penggunaan media harus disesuaikan dengan tujuan yang akan dicapai dan materi yang akan disampaikan dalam proses pembelajaran, karena jikalau penggunaan media tidak sesuai dengan materi yang akan disampaikan maka media yang digunakan guru bukan lagi sebagai alat bantu proses pembelajaran akan tetapi sebagai penghambat didalam mencapai tujuan pembelajaran.

Secara umum media pendidikan memiliki kegunaan-kegunaan sebagai berikut :

1. Memperjelas penyajian pesan agar tidak terlalu bersifat verbalitas (dalam bentuk kata-kata tertulis atau lisan)

2. Mengatasi keterbatasan ruang, waktu dan daya indra, seperti misalnya:

a. Objek yang terlalu besar bisa diganti dengan realita, gambar, film atau model.

b. Objek yang terlalu kecil bisa dibantu dengan proyektor mikro, film atau bingkai.

c. Konsep yang terlalu luas (gunung berapi, gempa bumi, iklim, dan lain-lain) dapat disajikan dengan model, diagram dan lain-lain.

Berikut ini dapat dijabarkan cara menggunakan media kongkrit pada penelitian ini : 
1. Siswa mengamati contoh kongkrit dari berbagai gambar keguiatan ekonomi yang telah guru sediakan.

2. Siswa menunjukan macam-macam kegiatan ekonomi dilingkungan sekitar.

3. Guru memberikan demonstrasi didepan kelas dengan menggunakan media pembelajaran yang telah disediakan.

\section{PELAKSANAAN PENELITIAN PERBAIKAN PEMBELAJARAN}

\section{A. Subyek, Tempat, dan Waktu Penelitian, Pihak Yang Membantu}

\section{Subyek dan Tempat Penelitian}

Penelitian ini dilaksanakan di kelas IV SD Neheri Limo 3 Jalan Rajawali No. 76 Kelurahan Limo, Kecamatan Limo, Kota Depok. Peneliti memilih sekolah tersebut sebagai tempat penelitian karena sekolah tersebut memenuhi persyaratan untuk dilakukan penelitian, sarana dan prasarananya sudah cukup memadai, dan jumlah peserta didik yang sesuai untuk dijadikan sampel penelitian.

\section{Waktu Pelaksanaan}

Waktu penelitian ini dilaksanakan pada semester genap tahun pelajaran 2015/2016 tepatnya mulai bulan Desember 2015-Agustus 2016.

\section{Pihak Yang Membantu Penelitian}

a. Kepala Sekolah SD Negeri Limo 3 Bapak Ridwan, S.Pd

b. Supervisor II Ibu Maisaroh, S.Pd.SD

\section{B. Desain Prosedur Perbaikan Pembelajaran}

Dalam hal perbaikan penelitian yang digunakan oleh peneliti adalah penelitian tindakan kelas yang terdiri dari tiga siklus, yaitu prasiklus, siklus I dan siklus II, pada setiap siklus masing-masing meliputi perencanaan, pelaksanaan, pengamatan, dan refleksi.

\section{Pra Siklus}

a. Tahap Perencanaan 
Dalam tahap perencanaan penulis melakukan kegiatankegiatan yang akan dilaksanakan dalam Perencanaan Pembelajaran, kegiatan tersebut diantaranya :

1. Penelitian prasiklus dimulai pada hari Rabu, 13 Januari 2016

2. Membuat Rencana Pembelajaran (RP)

3. Penulis menganalisis kurikulum untuk mengetahui dan menentukan kompetensi dasar yang akan diajarkan dengan menggunakan media papan tulis dan spidol

4. Membuat alat evaluasi hasil belajar

5. Menunjukan teman sejawat sebagai supervisor 2

b. Tahap Pelaksanaan

Pada kegiatan awal (15menit) penulis merencanakan kegiatan sebagai berikut :

1. Siswa menyimak penjelasan guru tentang aktivitas ekonomi yang berkaitan dengan sumber daya alam dan potensi lain di daerahnya.

2. Guru dan siswa melakukan tanya jawab tentang materi yang disampaikan

3. Guru membentuk kelompok dalam belajar.

Pada kegiatan inti (40 menit) kegiatan yang akn dilakukan adalah :

1. Guru bertanya kepada siswa tentang aktivitas ekonomi yang berkaitan dengan sumber daya alam dan potensi lain di daerahnya.

2. Melalui tanya jawab siswa menyebutkan aktivitas ekonomi yang berkaitan dengan sumber daya alam dan potensi lain di daerahnya.

3. Guru menuliskan 3 contoh aktivitas ekonomi yang berkaitan dengan sumber daya alam dan potensi lain di daerahnya.

4. Siswa ditugaskan untuk menuliskan 3 aktivitas ekonomi yang berkaitan dengan sumber daya alam dan potensi lain di daerahnya.

Pada kegiatan akhir (20 menit), kegiatan yang akan dilakukan adalah : 
1. Mengevaluasi pembelajaran

2. Tindak lanjut dengan pemberian tugas rumah

3. Berdoa dan salam

c. Tahap pengamatan / Teknik Pengumpulan Data

Berdasarkan pengamata dan observasi yang dilakukan oleh teman sejawat, maka ditemukan beberapa hal yang menjadi permasalahan yaitu :

1. Peserta didik tidak dapat menjawab pertanyaan secara benar yaitu $66,67 \%$ sedangkan yang dapat menjawab sebesar 33,33\% sehingga hasil kurang memuaskan tidak sesuai dengan KKM yang ditentukan yaitu 70,00.

2. Peserta didik kurang termotivasi dalam pelaksanaan pembelajaran.

3. Peserta didik kurang memahami materi.

4. Peserta didik pasif dan kurang memahami materi pelajaran

5. Media dan metode yang digunakan kurang tepat.

d. Tahap Refleksi

Dari hasil penelitian yang dilaksanakan ditemukan beberapa masalah yaitu : peserta didik kurang termotivasi, pembelajaran yang membosankan, pertanyaan-pertanyaan guru tidak terjawab dengan benar oleh peserta didik, dan penggunaan metode yang kurang tepat. Dari hasil evaluasi peserta didik, masih rendah itu dilihat dari nilai siswa yang belum mencapai KKM yaitu 70,00, pada hasil evaluasi 12 orang peserta didik yagn mendapat nilai diatas KKM atau 33,33\% dengan nilai rata-rata 61,87 .

\section{Siklus 1}

a. Tahap perencanaan

Untuk melaksanakan Siklus 1 akan disiapkan beberapa perencanaan sebagai berikut :

1. Identifikasi masalah dan penetapan alternative pemecahan masalah. 
2. Berkordinasi dengan teman sejawat selaku supervise 2 yang akan membantu pelaksanaan perbaikan pembelajaran.

3. Meminta izin kepada kepala sekolah tentang pelaksanaan perbaikan pembelajaran yang peneliti lakukan.

4. Merencanakan pembelajara yang akan diterapkan dalam proses belajar mengajar (rencana perbaikan pembelajaran I) sebagai acuan perbaikan pembelajaran.

5. Menyusun format evaluasi.

6. Mengembangkan format observasi pembelajaran.

7. Menyiapkan format APKG 1 dan 2 untuk supervise 2.

b. Tahap Pelaksanaan

Penelitian tindakan kelas pada mata pelajaran IPS dilaksanakan Rabu, 20 Januari 2016 dengan bantuan teman sejawat. Adapun langkah-langkah pembelajarannya adalah sebagai berikut :

1. Kegiatan awal (10 menit)

Langkah-langkah yang akan dilakukan adalah :

a. Mengkondisikan kelas / siswa sebagai persiapan pembelajaran

b. Mengabsen keadaan siswa

c. Melakukan tepuk semangat

d. Melakukan apersepsi

e. Menjelaskan tujuan dan kegiatan pembelajaran yang akan dilakukan.

2. Kegiatan Inti (40 menit)

Kegiatan yang akan dilakuka adalah :

a. Peserta didik membaca kegiatan-kegiatan ekonomi dan potensi lain yang berada dilingkungan sekitar.

b. Peserta didik dapat menyebutkan aktifitas ekonomi yang berkaitan dengan sumber daya alam dan potensi lain didaerahnya.

c. Guru memberikan penjelasan secara rinci kepada peserta didik tentang kegiatan ekonomi dan potensi lain didaerahnya. 
d. Guru memberikan tugas kepada peserta didik mengenai materi yang telah dibahas.

3. Kegiatan akhir (20 menit)

Langkah-langkah yang akan dilakukan adalah :

a. Mengevaluasi pembelajaran (post-tes)

b. Tindak lanjut dengan pemberian tugas rumah

c. Berdoa dan salam

c. Pengamatan

Pada tahap ini dilaksanakan pengamatan terhadap pelaksanaan proses pembelajaran dibantu oleh teman sejawat sebagai pengamat. Hasil pengamatan dari teman sejawat dapat berupa catatan kekurangan guru dan aktifitas peserta didik selama pelaksanaan pembelajaran yaitu :

1. Supervise 2 melakukan observasi dengan format yang telah disediakan

2. Menilai hasil tindakan dengan format yang tersedia.

3. Dalm menyampaikan materi guru tidak optimal dalam memanfaatkan penggunaan media dan metode pembelajaran.

4. Guru terlalu banyak menggunakan metode ceramah sehingga peserta didik kurang terlibat secara aktif.

5. Guru kurang memberikan pertanyaan kepada peserta didik.

d. Refleksi

Dari hasil Penelitia Tindakan Kelas ditemukan bahwa peserta didik kurang termotivasi dalam pelaksanaan pembelajaran pada siklus I ditemukan kekuatan kelemahan dalam tindakan perbaikan pembelajaran yaitu :

1. kekuatan

a) Guru menjelaskan materi kegiatan-kegiatan ekonomi yang berkaita dengan alam dan potensi didaerahnya kepada peserta didik cukup baik 
b) Pemberian motivasi kepeserta didik membuat kegiatan pembelajaran semakin menyenangkan.

c) Guru membimbing peserta didik yang belum paham dalam mengerjakan soal evaluasi.

2. Kelemahan

a) Peserta didik yang belum memahami materi pasif bertanya

b) Masih ada beebrapa peserta didik yang kurang memperhatikan pembelajaran. Hal ini terlihat ada beberapa peserta didik yang asik bermain dan bercanda ketika pembelajaran berlangsung.

c) Hasil belajar peserta didik belum memuaskan baru mecapai $47,22 \%$.

Berdasarkan uraian diatas dapat disimpulkan bahwa diperlukan siklus II agar hasil belajar peserta didik meningkat.

\section{Siklus 2}

a. Tahap Perencanaan

Pada siklus II peneliti membuat sekenario rencana perbaikan pembelajaran yang dilaksanakan pada Rabu, 27 Januari 2016, dengan bantuan teman sejawat sebagai pengamat pelaksanaan perbaikan dengan perencanaan sebagai berikut:

1. Identifikasi masalah yang muncul pada perbaikan pembelajaran siklus I yang belum teratasi dan penetapan alternative pemecahan masalah.

2. Menentukan indikator hasil belajar.

3. Mengembagkan program tindakan pembelajaran pada siklus II.

4. Menyiapkan LKS, format evaluasi sebagai alat penilaian, lembar pengamatan guru dan peserta didik media yang digunakan yaitu media gambar, alat peraga, dan metode demonstrasi.

b. Tahap Pelaksanaan

1. Pada kegiatan awal (10 menit), penulis merencananakan kegiatan sebagai berikut : 
a) Mengkondisikan kelas / siswa sebagai persiapan pembelajaran

b) Mengabsen keadaan siswa

c) Melakukan tepuk semangat

d) Melakukan apersepsi

e) Menjelaskan tujuan dan kegiatan pembelajaran yang akan dilakukan.

2. Pada kegiatan inti (40 menit), kegiatan yang akan dilakukan penulis adalah :

a) Guru mengajak peserta didik menyimak "aktifitas ekonomi yang berkaitan dengan sumbe daya alam dan potensi lain diderahnya" untuk menambah wawasan.

b) Peserta didik membaca tentang aktifitas ekonomi yang berkaitan dengan sumber daya alam dan potensi lain diderahnya

c) Guru menjelaskan secara rinci kepada peserta didik tentang kegiatan ekonomi dengan media gambar.

d) Guru memberi kesempatan untuk berpikir, menganalisis, menyelesaikan masalah, dan bertindak tanpa rasa takut;

e) Guru mengajak siswa untuk berdiskusi melalui "Pertanyaan Pemahaman" berdasarkan gambar.

f) Dengan metode demonstrasi guru memeragakan atau mempertunjukan kepada peserta didik dengan menggunakan benda atau tiruan yang sesuai dengan materi disertai dengan penjelasan lisan.

g) Guru memfasilitasi peserta didik melalui pemberian tugas, diskusi, dan lain-lain untuk memunculkan gagasan baru baik secara lisan maupun tertulis;

3. Pada Kegiatan Akhir (20 menit) langkah-langkah yang akan dilakukan adalah :

a) Mengevaluasi pembelajaran (post-tes)

b) Tindak lanjut dengan pemberian tugas rumah 
c) Berdoa dan salam

c. Tahap Pengamatan / Observer

Pada tahap pengamatan teman sejawat mencatat hal-hal yang telah tercantum dalam format observasi selama proses pembelajaran, hasilnya :

1. Administrasi (RPP Siklus II) sudah disipkan dengan cukup lengkap dan baik.

2. Guru menguasai pembelajaran dengan cukup baik.

3. Penggunaan media gambar sebagai alat peraga dan penggunaan metode demonstrasi sangat mempermudah peserta didik untuk memahami materi kegiatan-kegiatan ekonomi yang terkaitan dengan alam dan potensi daerahnya.

4. Sumber bahan ajar disiapkan dan digunakan dengan baik.

5. Pengelolaan kelas cukup baik.

6. Keterampilan bertanya dari guru dapat menambah motivasi belajar peserta didik untuk lebih aktif dalam pembelajaran.

7. Pembelajaran telah didesain dengan baik.

8. Masih ada beberapa peserta didik yang kurang memperhatikan pembelajaran yaitu bercanda dan mengobrol.

9. Refleksi

Hasil refleksi pada pembelajaran siklus II sudah tuntas belajar atau semua peserta didik menguasai materi pelajaran dengan baik, dan hasilnya yaitu :

1. Kekuatan

a) Guru terus memotivasi peserta didik agar terlibat aktif dalam pembelajaran.

b) Peserta didik berani bertanya dan dapat menjawab pertanyaan guru dengan baik.

c) Nilai rata-rata kelas dari hasil evaluasi meningkat.

d) Jumlah peserta didik yang tuntas belajar meningkat dan yang belum tuntas jumlahnya menurun. 
e) Keterampilan mengajar guru semakin baik.

f) Dengan menggunakan media gambar dan metode demonstrasi pada kegiatan pembelajaran IPS materi kegiatan-kegiatan ekonomi berkaitan dengan alam dan potensi lain didaerahnya dapat meningkat hasil belajar peserta didik.

2. Kelemahan

a) Masih ada 3 peserta didik yang belum tuntas belajar.

b) Media yang digunakan kurang variatif

c) Sebaiknya menggunakan media yang lebih menarik untuk belajar.

\section{Tehnik Analisis Data}

Dalam hal ini tehnik analisis data dilakukan oelh peneliti dengan dengan cara deskriptif kualitatif yaitu mendeskripsikan setiap data yang diperoleh dari setiap siklusnya. Data tersebut kemudian dibandingkan dengan data dari masing-masing siklus untuk diketahui sejauh mana tingkat keberhasilan yang diperoleh peneliti perbaikan pembelajaran. Tahap pelaksanaan analisis data yaitu :

1. Peneliti melakuka perbaikan pembelajaran pada 2 siklus.

2. Peneliti mengumpulkan data hasil perbaikan pembelajaran yang berupa hasil evaluasi dari tiap siklus.

3. Hasil perbaikan pembelajaran siklus I dibandingkan dengan hasil perbaikan pembelajaran pada siklus II.

4. Hasil perbaikan pembelajaran dari tiap siklus ditentukan tingkat keberhasilannya.

5. Mengambil keputusan untuk melanjutkan atau tidak melanjutkan perbaikan pembelajaran pada siklus berikutnya.

\section{HASIL PENELITIAN DAN PEMBAHASAN}

\section{A. Deskripsi Hasil Perbaikan Pembelajaran}

Dalam Pelaksanaan Penelitian Tindakan Kelas, peneliti dibantu oleh rekan sejawat untuk mengobservasi dan memberikan masukan terhadap 
pelaksanaan pembelajaran yang akan dilakukan. Selanjutnya dalam proses pembelajaran, peneliti berdiskusi dengan rekan sejawat untuk menemukan kekurangan dalam proses pembelajaran yang telah dilakukan. Selain itu, peneliti melakukan refleksi atas pembelajaran yang dilakukan untuk memutuskan perbaikan pembelajaran selanjutnya. Instrumen yang dilakukan oleh peneliti sebagai berikut :

1. Instrumen pengamatan untuk mengetahui hasil belajar peserta didik.

2. Instrumen pengamatan peserta didik yang dapat menjawab pertanyaan guru dengan benar.

3. Lembar evaluasi per siklus.

Hasil refleksi pada proses pembelajaran mata pelajaran IPA yang telah dilaksanakan oleh peneliti yaitu sebagai berikut :

1. Motivasi belajar peserta didik dalam pembelajaran IPA masih rendah.

2. Peserta didik kurang menguasai materi pelajaran.

3. Peserta didik kurang tertarik dalam proses pembelajaran IPA.

4. Peserta didik kurang aktif dalam mengikuti pelajaran IPA.

Dalam proses belajar mengajar pada prasiklus diperoleh beberapa permasalahan, yaitu.

1. Nilai rata-rata peserta didik masih di bawah KKM yang telah ditetapkan.

2. Tangung jawab peserta didik terhadap tugas masih rendah.

3. Guru belum menggunakan metode pembelajaran yang tepat.

Berdasarkan hasil pembelajaran maka peneliti menemukan data tiap siklus. Data-data yang ditemukan adalah sebagai berikut :

\section{Prasiklus}

Pada prasiklus nilai rata-rata hasil evaluasi yang diperoleh sebesar 61 dengan jumlah peserta didik yang belum mencapai KKM sebanyak 18 (47\%) dari 38 peserta didik.

Berdasarkan hasil evaluasi Prasiklus diperoleh data 18peserta didik (47\%) mendapat nilai di bawah KKM, 12 peserta didik (32\%) mendapat nilai sama dengan KKM dan hanya 8 peserta didik (21\%) yang mendapat nilai di atas KKM. Melalui pengamatan, peserta didik yang dapat menjawab 
pertanyaan guru 36,84\% dan yang belum dapat menjawab sebesar 63,16\%. Berdasarkan tabel 3 di bawah, hasil pengamatan peserta didik yang dapat menjawab pertanyaan guru dengan benar sebanyak 14 dari 38 peserta didik atau sebesar $(36,84 \%)$ dan sejumlah 24 dari 38 peserta didik yang belum dapat menjawab pertanyaan guru dengan benar atau sebesar $(63,16 \%)$.

Dari data tersebut dapat diartikan bahwa tujuan pembelajaran belum tercapai sepenuhnya untuk itu perlu diadakan perbaikan pembelajaran. Perbaikan pembelajaran yang penulis lakukan untuk menindak lanjuti adalah 2 (dua) siklus perbaikan.

1

\section{Siklus I}

Pada siklus I peneliti menambah metode pembelajaran menjadi metode ceramah, diskusi, tanya jawab dan pemberian tugas. Hasil evaluasi peserta didik meningkat dengan hasil nilai rata-rata 69 yang mencapai ketuntasan sebanyak 28 peserta didik dan yang menjawab benar sebesar 55,26\%.

Berdasarkan hasil evaluasi Siklus I diperoleh data 10peserta didik (26\%) mendapat nilai di bawah KKM, 21 peserta didik (55\%) mendapat nilai sama dengan KKM dan hanya 7 peserta didik (19\%) yang mendapat nilai di atas KKM. Dari data tersebut dapat diartikan sudah terjadi peningkatan nilai dari Pra Siklus ke Siklus I.

Berdasarkan hasil pengamatan peserta didik yang dapat menjawab pertanyaan guru dengan benar sebanyak 21 dari 38 peserta didik atau sebesar $(55,26 \%)$ dan sejumlah 17 dari 38 peserta didik yang belum dapat menjawab pertanyaan guru dengan benar atau sebesar $(44,74 \%)$.

\section{Siklus II}

Berdasarkan nilai hasil evaluasi Siklus II diperoleh data 4peserta didik (11\%) mendapat nilai di bawah KKM, 13 peserta didik (34\%) mendapat nilai sama dengan KKM dan hanya 21 peserta didik (55\%) yang mendapat nilai di atas KKM. Dari data tersebut dapat diartikan sudah terjadi peningkatan yang signifikan nilai dari Pra Siklus sampai siklus II. Namun masih ada 4peserta didik yang nilainya di bawah KKM. 
Berdasarkan hasil pengamatan peserta didik yang dapat menjawab pertanyaan guru dengan benar sebanyak 27 dari 38 peserta didik atau sebesar $(71,05 \%)$ dan sejumlah 11 dari 38 peserta didik yang belum dapat menjawab pertanyaan guru dengan benar atau sebesar $(28,95 \%)$.

Dari hasil evaluasi pembelajaran siklus I, mata pelajaran IPA belum mencapai hasil yang diharapkan, sehingga peneliti melakukan perbaikan pembelajaran pada siklus II. Hasil dari perbaikan pembelajaran pada siklus II mencapai ketuntasan 34 peserta didik dari 38 peserta didik atau sebesar $89 \%$ dengan nilai rata-rata 81 dan hasil pengamatan sebesar 71,05\%.

Hasil Rencana Pembelajaran (RP) Prasiklus hasil perolehan evaluasi peserta didik hanya mencapai $33,33 \%$ peserta didik yang mendapat nilai 70 keatas hanya 13 sedangkan yang tidak dapat menjawab 23 dengan demikian, bahwa penilaian tersebut kurang memuaskan, hal ini disebabkan karna belum menggunakan media yang tepat. Untuk itu maka penulis melanjutkan dengan kegiatan perbaikan pembelajaran pada siklus I.

Pada siklus I penulis memperbaiki pelaksanaan perbaikan pembelajaran dengan menggunakan pendekatan pembelajaran yang lebih bervariatif yaitu dengan bertanya jawab dan pemberian tugas, terjadi peningkatan ini dapat dilihat dari 36 peserta didik yang dapat nilai diatas 70 yaitu ada 17 peserta didik, dengan tingkat keberhasilan 47,22 dengan hasil nilai rata-rata 68,17 , kemudian peserta didik yang dapat menjawab hanya 17 , sedangkan yang tidak dapat menjawab ada 19. Dari keterangan diatas penulis melanjutkan perbaikan pembelajaran pada siklus 2 agar hasil yang didapat oleh siswa lebih baik lagi.

Pada perbaikan pembelajaran pada siklus 2 penulis menambahkan media gambar dan metode demonstrasi. Dengan menggunakan media gambar dan metode demonstarasi pembelajaran yang dilaksanakan menunjukan kemajua, hal ini dapat dilihat dari perolehan hasil belajar peserta didik yang mencapai nilai 70 ketas yaitu 33 peserta didik dengan tingkat keberhasilan $91,67 \%$ dengan hasil nilai rata-rata 81,22 dn yang belum mencapai nilai KKM hanya 3 peserta didik atau sebanyak $8,33 \%$. 
Dari penjelasan diatas dapat disimpulkan bahwa perbaikan pembelajaran akan menunjukan kemajuan jika menggunakan media yang tepat sebagaimana peneliti menggunakan metode demonstrasi dan media gambar dapat meningkatkan hasil belajar peserta didik secara segnifikan.

\section{SIMPULAN, SARAN DAN TINDAK LANJUT}

\section{A. Simpulan}

Dari hasil proses perbaikan pembelajaran yang telah dilaksanakan oleh penulis pada mata pelajaran IPS kelas IV dengan materi kegiatan ekonomiyang dilakukan sebanyak dua siklus, penulis dapat menarik kesimpulan sebagai berikut :

1. Dari hasil prasiklus, tingkat ketuntasan hasil belajar peserta didik mencapai nilai KKM 70, hanya 12 dari 36 peserta didik atau 33,33\% dengan nilai rata-rata 61,78 dan dari hasil pengamatan peserta didik yang tidak dapat menjawab 66,67\%. Pada Siklus I, 17 peserta didik yang sudah tuntas sebesar 47,22\% dengan niali rata-rata 68,22. Dari prasiklus dan siklus I, maka siklus II dengan menggunakan metode demonstrasi dan media gambar peserta didik yang mengalami ketuntasan 91,66\% dengan perolehan nilai rata-rata sebesar 81,22, dan dengan pengamatan peserta didik yang dapat menjawab pertanyaan dengan benar $91,66 \%$.

2. Dengan menggunakan metode demonstrasi dan media gambar dapat meningkatkan hasil belajar peserta didik dengan segnifikan pada materi kegiatan ekonomi yang berkaitan dengan alam dan lingkungan sekitar.

\section{B. Saran dan Tindak Lanjut}

Berdaarkan kesimpulan diatas, penulis menyarankan, untuk dapat meningkatkan penguasaan materi dan peningkatan pemahaman peserta didik terhadap materi pembelajaran agar dilakukan hal-hal sebagai berikut :

1. Menggunakan media gambar kegiatan ekonomi yang terdapat dilingkungan sekitar tempat tinggal peserta didik dn metode demonstrasi 
sebagai sarana untuk meningkatkan semangat dan hasil belajar peserta didik.

2. Menyiapkan kegiatan belajar mengajar yang kondusif, menyenangkan, dan interaktif agar dapat meningkatkan hasil belajar peserta didik.

\section{Referensi}

Purwanto. 2011. Evaluasi Hasil Belajar. Yogyakarta: Pustaka Belajar.

Sapriya. 2014. Pendidikan IPS Konsep dan Pembelajaran. Bandung: Remaja Rosdikarya.

Sudirman N. dkk. 1991. Ilmu Pendidikan. Bandung : Remaja Rosdakarya.

Sulfemi, Wahyu Bagja. (2013). Pengaruh Persepsi Siswa atas Kemampuan Pedagogik Guru dan Motivasi Belajar Siswa Terhadap Prestasi Belajar Ilmu Pengetahuan Sosial Siswa (Survei di SMK Swasta Kabupaten Bogor). Edutecno. 7 (2), 17-26.

Sulfemi, Wahyu Bagja. (2014). Pengaruh Motivasi dan Lingkungan Sekolah Terhadap Prestasi Belajar Sejarah Di SMA Negeri Leuwilang Kabupaten Bogor. Fascho : Kajian Pendidikan dan Sosial Kemasyarakatan 9 (2), 42-52

Sulfemi, Wahyu Bagja. (2015). Pengaruh Metode Pembelajaran Kontekstual dan Penggunaan Media Video Pendidikan Terhadap Hasil Belajar IPS. Edutecno 13 (2), 1-10

Sulfemi, Wahyu Bagja. (2016). Hubungan Persepsi Peserta Didik Tentang Kompetensi Guru Mata Pelajaran Sejarah dengan Hasil Belajar Mata Pelajaran Sejarah di Kelas X SMA Negeri 1 Pamijahan Kabupaten Bogor. Fascho, 5 (2), 52-70

Sulfemi, Wahyu Bagja. (2016). Hubungan antara Persepsi Guru pada Kepemimpian Kepala Sekolah dan Motivasi Guru dengan Kinerja guru dalam Proses Pembelajaran di SMA Negeri 1 Ciomas. Fascho : Kajian Pendidikan dan Sosial Kemasyarakatan, 5 (1), 36-55

Sulfemi, Wahyu Bagja. (2016). Perundang-Undangan Pendidikan. Bogor : Program Studi Administrasi Pendidikan STKIP Muhammadiyah Bogor.

Sulfemi, Wahyu Bagja dan Lestari, Ayu Hopilatul. (2017). Korelasi Kompetensi Pedagogik Guru dengan Prestasi Belajar Mata Pelajaran IPS Di SMP Muhammadiyah Pamijahan Kabupaten Bogor. Edutecno. 16 (1), 116 
Sulfemi, Wahyu Bagja dan Abdul Qodir. (2017). Hubungan Kurikulum 2013 Dengan Motivasi Belajar Peserta Didik Di SMK Pelita Ciampea. Edutecno 17 (2), 1-8.

Sulfemi, Wahyu Bagja. (2017). Analisis Pengaruh Motivasi Dan Disif... Terhadap Kinerja Guru (Studi Kasus di SMA Negeri 1 Pamijahan Kabupaten Kabupaten Bogor). Prosiding Seminar Nasonal STKIP Muhammadiyah Bogor. 1 (1), 342-357

Trianto. 2009. Mendesain Model Pembelajaran Inovatif-Progresif. Surabaya : Prenada Media Group

Umar, Aji H. dkk. 2012. Pendidikan dan Pelatihan Profesi Guru Sekolah Dasar. Jakarta: Universitas Negeri Jakarta. 